\title{
Drug use and antisocial behavior among adolescents attending public schools in Brazil
}

\author{
Uso de drogas e comportamento antissocial entre adolescentes \\ de escolas públicas no Brasil
}

Fernanda Lüdke Nardi, ${ }^{1}$ Silvia Mendes da Cunha, ${ }^{1}$ Lisiane Bizarro, ${ }^{2}$ Débora Dalbosco Dell'Aglio ${ }^{3}$

\begin{abstract}
Introduction: Drug use is a social and a public health problem that has been related with antisocial behavior. The aim of this study was to evaluate the relationship between drug use and antisocial behavior among adolescents attending public schools in Brazil.

Method: A total of 7,176 adolescents from low-income neighborhoods and public schools aged 14 to 19 years were assessed in five geographical regions in Brazil. Data on biosociodemographic characteristics and on drug use and antisocial behavior were assessed from complete answers to a national survey on risk and protective factors among adolescents.

Results: Over $80 \%$ of the adolescents who used alcohol and cigarettes were between 14 and 17 years old. The percentage of participants with antisocial behaviors was significantly higher among users of marijuana, cocaine, or crack than among adolescents who were not drug users.
\end{abstract}

Conclusions: Prevention programs aimed at reducing substance use might help to decrease antisocial behaviors.

Keywords: Adolescent, adolescent behavior, drug users.

\section{Introduction}

Drug use and abuse is a social and public health problem in most countries worldwide, as a result of the several negative effects it may have on people's emotional and physical development. ${ }^{1}$ Studies have pointed to an association between drug use and antisocial behaviors, ${ }^{1-7}$ which can be described as disrespectful behavior and violation of rights. ${ }^{8}$ Notwithstanding, it is difficult to determine whether such behaviors happen before or

\section{Resumo}

Introdução: $O$ uso de drogas é um problema social e de saúde pública que tem sido relacionado a comportamentos antissociais. O objetivo deste estudo foi avaliar a relação entre uso de drogas e comportamento antissocial em adolescentes de escolas públicas no Brasil.

Método: No total, 7.176 jovens com idades entre 14 e 19 anos estudantes de escolas públicas das cinco regiões geográficas do Brasil foram avaliados. Foram utilizados dados biossociodemográficos e sobre uso de drogas e comportamento antissocial obtidos na Pesquisa Nacional sobre Fatores de Risco e Proteção da Juventude Brasileira. Resultados: Mais de $80 \%$ dos adolescentes que fizeram uso de bebidas alcoólicas e cigarro tinham entre 14 e 17 anos. O percentual de pacientes com comportamento antissocial foi significativamente maior entre usuários de maconha, cocaína ou crack do que entre adolescentes não usuários.

Conclusões: Programas de prevenção direcionados à redução do uso de substâncias poderiam trazer uma diminuição dos comportamentos delinquentes.

Descritores: Adolescente, comportamento do adolescente, usuários de drogas.

after the start of drug use. As already pointed out, the act of using drugs in itself introduces the individual into the world of youth delinquency, a term used to refer to antisocial behaviors - such as criminal offences - among adolescents. ${ }^{8-10}$ Such offences would include not only the illicit use of drugs, but also the offences committed with the purpose of obtaining money to buy drugs. ${ }^{3}$

After the 1980s, an increase in drug use was observed among Brazilian students. ${ }^{11}$ The drugs most frequently

\footnotetext{
${ }^{1}$ MSc in Psychology, Universidade Federal do Rio Grande do Sul (UFRGS), Porto Alegre, RS, Brazil. PhD candidate, Psychology, UFRGS. ${ }^{2}$ PhD in Psychology, Institute of Psychiatry, King's College of London, London, UK. Associate professor, Graduate Psychology Program, UFRGS. ${ }^{3}$ PhD in Psychology, UFRGS. Associate professor, Graduate Psychology Program, UFRGS.

Submitted Dec 14 2010, accepted for publication Jun 9 2011. No conflicts of interest declared concerning the publication of this article.

Suggested citation: Nardi FL, Cunha SM, Bizarro L, Dell'Aglio DD. Drug use and antisocial behavior among adolescents attending public schools in Brazil. Trends Psychiatry Psychother. 2012;34(2):80-6.
} 
used by adolescents in Brazil are alcohol and tobacco. ${ }^{12}$ The II Home Survey on the Use of Drugs in Brazil (II Levantamento Domiciliar Sobre Uso de Drogas no Brasil), carried out in 2005 by the Brazilian Center for Psychotropic Drug Information (Centro Brasileiro de Informações sobre Drogas Psicotrópicas, CEBRID), ${ }^{13}$ found that $54.3 \%$ of adolescents aged 12 to 17 years had already used alcohol at least once, and $7.3 \%$ were dependent on this substance. In the same age group, $15.2 \%$ of lifetime use and $2.9 \%$ of dependence on tobacco were observed. Other substances already used by adolescents included marijuana (4.1\%), cocaine $(0.5 \%)$, and crack $(0.1 \%) .{ }^{13}$ Another survey revealed that, in Brazil, alcohol consumption starts at around 13 years of age: $35 \%$ of adolescents at this age consume alcohol at least once a month. ${ }^{14}$ Adolescents have easy access to alcoholic beverages in parties, bars, or other commercial facilities in Brazil, ${ }^{15}$ despite the fact that selling alcohol to subjects under 18 years of age is illegal in the country.

A report on drug and crime published by the United Nations in $2010^{16}$ disclosed up-to-date data on the consumption and trafficking of drugs in Brazil. According to the document, $6.3 \%$ of students aged 15 to 16 years use marijuana at least once yearly. With regard to cocaine, Brazil and Argentina are the countries with the largest markets for this drug in South America (over 900 and 600 thousand users, respectively).

There is no consensus on the causal relationship between drug use and antisocial behaviors. Whereas many studies point to offences as happening before the use of drugs, others suggest that drug use is one of the causes of delinquency. Nevertheless, it is important to emphasize that the two hypotheses are not mutually exclusive.

Since the 1980s, there has been evidence that drug abuse or dependence among adolescent offenders would be related with severity of antisocial behavior. ${ }^{17} \mathrm{~A}$ longitudinal study on the relationship between alcohol/ marijuana use and delinquent behavior among 506 adolescents found that illegal acts committed under the influence of drugs were more prevalent among youth with more severe antisocial behaviors. ${ }^{18}$ Nevertheless, more recent evidence suggests that conduct problems and delinquency often precede the onset of substance abuse. ${ }^{19}$ In 1997, a study was designed to assess whether drug use or criminal history predicted the occurrence of antisocial behaviors, e.g. problems with the police, family conflicts, and violence. The use of substances, when considered in combination with other variables, proved to be only a mild predictor of delinquency, accounting for five of the 21 types of behaviors assessed. Conversely, criminal history was shown to be an extremely strong variable, accounting for the majority of acts investigated. ${ }^{20}$ This understanding is shared by the authors of another longitudinal study that assessed adolescents aged 11 to 17 years and found that adolescents with an early start in criminal activity developed chemical dependence earlier and showed drug-related problems faster than those who did not start delinquency or started it late in life. ${ }^{21}$ Also, drug use was observed to be more frequent among adolescents in conflict with the law than among adolescents attending public schools, especially marijuana, cocaine, and crack, which seem to be the drugs with greatest potential to interfere with conduct behaviors and to motivate violent behaviors. ${ }^{5,6}$ The use of drugs (except alcohol and cigarette) was also more frequent among children and adolescents from a juvenile institution who had committed offences than among those who had not. ${ }^{13}$

When an individual identifies with a delinquent group, a context in which antisocial behaviors are stimulated may be created, including the initiation and maintenance of drug use. ${ }^{4}$ Adolescents who commit offences tend to relate with drug users, ${ }^{22}$ and group pressure is known to be a strong determinant of drug use. ${ }^{1}$ When taken as a social activity, drug use facilitates coexistence with peers who encourage or reinforce illegal behaviors. ${ }^{23}$ The relationship between drug use and delinquency is further supported by the fact that similar causes are involved in the development of the two types of behavior, ${ }^{4}$ e.g. not having or having a distant family. ${ }^{24}$ Also, drugs may interact with personality or temperament traits, such as impulsivity or hyperactivity, increasing the risk for delinquency. ${ }^{25}$ However, some personality characteristics, such as self-esteem and self-fulfillment, have been shown to relate with substance use, but not with delinquency. ${ }^{4}$

Loeber \& Hay ${ }^{26}$ distinguish between two types of causes underlying juvenile delinquency: the first type would have visible effects only after long periods of time, e.g. exposure to violence and ineffective parental educational practices, such as neglect and physical abuse ${ }^{27}$; the second type would include all those causes with more immediate effects, e.g. drug consumption. ${ }^{26}$ As a result, delinquent behavior and drug use should be understood under different perspectives, taking into consideration the cultural background of adolescents and the meaning of drug use among their peers. Moreover, it is necessary to consider the developmental stage of these individuals: adolescence is marked by a desire for different forms of expression, which may also include antisocial manifestations. ${ }^{28}$

One possible explanation for the etiology common to both delinquent/antisocial behavior and drug use has been provided by the behavioral disinhibition theory. ${ }^{29}$ According to that theory, behavioral disinhibition would involve novelty seeking behaviors, a low risk perception, lack of control, and inability to inhibit pleasure and maladaptive 
impulses. ${ }^{30}$ In other words, behavioral disinhibition may be defined as a generalized vulnerability to externalizing disorders, and may be associated with impairment of executive functions, or an inability to inhibit responses. ${ }^{29}$

For example, studies have revealed that being a smoker is related with externalizing characteristics and antisocial personality ${ }^{30,31}$; an association between these factors and drug abuse has also been observed. ${ }^{30}$ Moreover, the diagnosis of conduct disorder in childhood may be a predictor of the abuse of psychoactive substances in adolescence. ${ }^{29}$

Based on the above, the objective of this study was to assess the relationship between drug use and antisocial behaviors in adolescents attending public schools. Selected participants from a national survey were described with regard to biosociodemographic data, drug use in the past year (alcoholic beverages, cigarettes, marijuana, crack cocaine, and cocaine) and antisocial behaviors (having been involved in drug trafficking, having been arrested, and having had problems with justice).

\section{Method}

\section{Participants}

This study used information from the database of the National Survey on Risk and Protective Factors among Brazilian Youth (Pesquisa Nacional sobre Fatores de Risco e Proteção da Juventude Brasileira), ${ }^{32}$ performed between 2005 and 2007. In order to compose a sample of adolescents in social vulnerability condition, neighborhoods of low socioeconomic status were identified in each participating city. Neighborhood selection was based on the human development index for the state of São Paulo or on social indicators established by the Brazilian Institute of Geography and Statistics (Instituto Brasileiro de Geografia e Estatística, IBGE), namely, family income, educational level, household conditions (e.g. water treatment and sewage), and overall conditions described in the 2000 Census. Following the identification of neighborhoods, participating schools were selected by drawing lots.

For the scope of the present study, questionnaires with missing answers for the questions analyzed were excluded from the sample $(n=592)$. As a result, data from a total of 7,176 adolescents with a low socioeconomic status were analyzed; age ranged between 14 and 19 years $($ mean $=15.87$; standard deviation $=1.35$ ), and $54.9 \%$ ( $n=3,937)$ were female.

The adolescents attended public schools located in neighborhoods with social vulnerabilities; the majority was attending between the 8th grade of the elementary school and the 2 nd grade of high school. The sample included participants from the five geographic regions of Brazil, namely North, Northeast, Central-West, Southeast, and South Regions, including six state capitals and three medium-sized cities. The age range selected for analysis was between 10 and 19 years, based on the definition of adolescence from the World Health Organization. ${ }^{33}$

\section{Instrument}

For the scope of the present study, sociodemographic data and answers to questions/statements 69 and 89 from a questionnaire previously applied as part of the project mentioned above (Pesquisa Nacional sobre Fatores de Risco e Proteção da Juventude Brasileira) ${ }^{32}$ were used. Question/statement no. 69 focused on drug experimentation and drug use in the past month and also in the past year, whereas question/statement no. 89 covered involvement in antisocial behaviors, e.g. having been arrested, having been involved in drug trafficking, and having had problems with justice

The questionnaire was designed by Koller et al. ${ }^{34}$ and contains 109 self-report questions or statements with multiple-choice or Liker-type answers. Questions/ statements addressing the use of drugs were based on a previous survey conducted by CEBRID ${ }^{13}$ that covers sociodemographic characteristics, educational level, family characteristics, health status, sexual activity, drugs, violence, leisure, religious aspects, social support, mood, optimism, self-efficacy, and self-esteem.

Data were collected between 2005 and 2007 in classrooms with 30 to 35 students, plus three to four members of the research team and the research coordinator. Research teams comprised one health professional with graduate studies in psychology (local co-coordinator) and 8 to 12 assistants, either psychologists or psychology students. Teams were continuously supervised by the research coordinator. Questionnaire application lasted for up to 2 hours. These procedures were approved by the Research Ethics Committee of Universidade Federal do Rio Grande do Sul. All applicable regulations were observed.

\section{Statistical analysis}

Descriptive analyses were performed to assess the frequency of use of alcohol, cigarettes, and illicit drugs (marijuana, cocaine, and crack) and of the antisocial behaviors investigated (having been involved in drug trafficking, having been arrested, and having had problems with justice). The chi-square test was used to assess the association between drug use in the past year and variables related with antisocial behavior. 


\section{Results}

Rates of experimentation and use of alcoholic beverages and cigarettes in the past year and in the past month were higher when compared with other drugs (Table 1 ). In a comparative analysis, adolescents aged 14 to 17 years showed a higher use of wine and beer in the past year (86.6\%) when compared with those aged 18 and 19 years. Also with regard the $14-17-y e a r$ age group, $85.3 \%$ of the participants had consumed other alcoholic beverages and $84.7 \%$ had smoked cigarettes in the past year.

Crack consumption (both experimentation and use in the past year and month) was observed among the adolescents analyzed (Table 1). Antisocial behaviors were also observed among the adolescents investigated: 289 (4\%) participants had already been involved with drug trafficking, $310(4.3 \%)$ had had problems with justice, and $262(3.7 \%)$ had already been arrested. Among the participants previously involved with drug trafficking, $34.5 \%$ had had problems with justice, and $27.7 \%$ had been arrested.

Alcohol use (beer, wine, and other alcoholic beverages) or cigarette smoking were not associated with antisocial behaviors. However, significant associations were observed between such behaviors and the use of other drugs (marijuana, cocaine, and crack) in the past year (Table 2). Participants who reported having used drugs showed significantly higher frequencies of having been arrested, having been involved in drug trafficking, and having had problems with justice when compared with participants who did not use such drugs.
Having been arrested was significantly associated with the use of cocaine $\left(x^{2}=31.7 ; p<0.001\right)$, the use of crack $\left(X^{2}=27.7 ; p<0.001\right)$ and the use of marijuana in the past year $\left(X^{2}=79.5 ; p<0.001\right)$. A significant association was also observed between involvement in drug trafficking and cocaine use $\left(x^{2}=233.4 ; p<0.001\right)$, crack $\left(X^{2}=133 ; p<0.001\right)$ and marijuana use $\left(X^{2}=\right.$ $326.4 ; p<0.001)$ in the past year. Finally, having had problems with justice was associated with cocaine use $\left(X^{2}=177.1 ; p<0,001\right)$, crack use $\left(X^{2}=91.7 ; p<\right.$ $0.001)$ and marijuana use $\left(x^{2}=205 ; p<0.001\right)$.

\section{Discussion}

The present study revealed that a high number of participants tried or regularly used alcoholic beverages and/or cigarettes in the past year when compared with data from a previous survey conducted with students of elementary, middle and high school in 27 Brazilian capitals by CEBRID and by the National Secretariat for Drug Policies (Secretaria Nacional de Políticas Sobre Drogas, SENAD). ${ }^{35}$ Moreover, in the present study, as also observed in the CEBRID/SENAD survey, ${ }^{35}$ alcohol and cigarettes were the drugs most frequently used among students. It is important to emphasize that subjects were aged 14 to 19 years (minors), and that selling or distributing such substances to children and adolescents is a criminal offence. ${ }^{36}$ However, in Brazil, adolescents have easy access to alcoholic beverages at commercial facilities and also in social contexts, e.g.

Table 1 - Frequency and percentage of drug experimentation and drug use in the past year and in the past month

\begin{tabular}{|c|c|c|c|c|c|c|}
\hline \multirow[b]{2}{*}{ Substance } & \multicolumn{2}{|c|}{ Experimentation } & \multicolumn{2}{|c|}{ Use in the past year } & \multicolumn{2}{|c|}{ Use in the past month } \\
\hline & $\mathbf{n}$ & $\%$ & $\mathbf{n}$ & $\%$ & $\mathbf{n}$ & $\%$ \\
\hline Wine or beer & 5,103 & 71.1 & 2,856 & 39.8 & 1,809 & 25.2 \\
\hline Other alcoholic beverages & 2,929 & 40.8 & 1,628 & 22.7 & 1,052 & 14.7 \\
\hline Cigarette & 1,805 & 25.2 & 766 & 10.7 & 548 & 7.6 \\
\hline Marijuana & 466 & 6.5 & 207 & 2.9 & 112 & 1.6 \\
\hline Cocaine & 162 & 2.3 & 77 & 1.1 & 39 & 0.5 \\
\hline Crack & 88 & 1.2 & 41 & 0.6 & 28 & 0.4 \\
\hline
\end{tabular}

Table 2 - Frequency and percentage of associations between drug use in the past year and antisocial behaviors

\begin{tabular}{|c|c|c|c|c|c|c|}
\hline \multirow[b]{2}{*}{ Substance } & \multicolumn{2}{|c|}{ Arrested, n (\%) } & \multicolumn{2}{|c|}{ Drug trafficking, n (\%) } & \multicolumn{2}{|c|}{ Problems with justice, n (\%) } \\
\hline & Yes & No & Yes & No & Yes & No \\
\hline \multicolumn{7}{|l|}{ Cocaine } \\
\hline Yes & $12(16.7)$ & $60(83.3)$ & $30(42.3)$ & $41(57.7)$ & $26(35.6)$ & $47(64.4)$ \\
\hline No & $170(3.7)$ & $4,421(96.3)$ & $184(4)$ & $4,406(96)$ & $204(4.5)$ & $4,341(95.5)$ \\
\hline \multicolumn{7}{|l|}{ Crack } \\
\hline Yes & $8(20)$ & $32(80)$ & $17(42.5)$ & $23(57.5)$ & $15(37.5)$ & $25(62.5)$ \\
\hline No & $174(3.8)$ & $4,434(96.2)$ & $195(4.2)$ & $4,410(95.8)$ & $211(4.6)$ & $4,350(95.4)$ \\
\hline \multicolumn{7}{|l|}{ Marijuana } \\
\hline Yes & $31(16.4)$ & $158(83.6)$ & $60(31.7)$ & $129(68.3)$ & $52(27.2)$ & $139(72.8)$ \\
\hline No & $155(3.5)$ & $4,330(96.5)$ & $157(3.5)$ & $4,324(96.5)$ & $181(4.1)$ & $4,254(95.9)$ \\
\hline
\end{tabular}


parties with relatives and friends, ${ }^{16}$ which demonstrates the social acceptance of alcohol use in adolescence. ${ }^{37}$

The antisocial behaviors investigated in the present study showed an approximate rate of $4 \%$ among the adolescents assessed. Previous studies conducted by the United Nations Latin American Institute for the Prevention of Crime and the Treatment of Offenders (Instituto Latino-Americano das Nações Unidas para Prevenção do Delito e Tratamento do Delinquente, ILANUD) have shown that criminal offences committed by adolescents in Brazil do not exceed $10 \%$ of the total of offences recorded. In addition, of the total number of offences perpetrated by adolescents, the great majority (over $70 \%$ ) are crimes against property. ${ }^{38}$ Based on such findings, it is possible to hypothesize that the lower rate of criminal offences found in our study could reflect the social context of participants, once our adolescents were students. School may be considered as a strong protective factor against juvenile delinquency, once it offers a positive environment and the establishment of pro-social relationships among students and teachers. ${ }^{39,40}$ Regular school attendance may reduce crime severity and drug use. ${ }^{41} \mathrm{~A}$ recent study with delinquent adolescents revealed that only $42 \%$ of them attended school. ${ }^{42}$

With regard to the relationship between antisocial behaviors and drug use, it is important to take into consideration that the use of drugs in itself is an antisocial conduct. Once the adolescent agrees to make use of illicit substances, he/she may also agree to engage in other criminal offences (both situations involve violation of law). ${ }^{4}$ This could explain the association between use of marijuana, cocaine, and crack on the one hand, and antisocial behaviors on the other. Conversely, no associations were found between the use of alcohol or cigarette in the past year and criminal involvement. Marijuana was the drug most frequently used among the 196 adolescents who committed offences and sought treatment at a juvenile institution in Porto Alegre, southern Brazil, in a study that reported a $61 \%$ prevalence of use of drugs among participants. ${ }^{42}$

Based on the associations here observed, some aspects of the relationship between use of psychoactive substances and engagement in antisocial behaviors deserve to be discussed. The percentage of youngsters that confirmed having used illicit drugs (crack, cocaine, and marijuana) in the past year was significantly higher among adolescents who reported engagement in antisocial behaviors. Such association could be explained by the behavioral disinhibition, or an impaired control of impulses and inability to inhibit pleasure. ${ }^{30}$

Another possible explanation for our findings could be the effects of psychoactive substances on human behavior. ${ }^{18}$ Some authors ${ }^{4}$ have described the psychopharmacological effects of intoxication by drug use, e.g. disinhibition and cognitive distortions. Also, although economic motivations only partly explain the complex universe of the illicit drug market, property crime allows these adolescents to buy the drug. ${ }^{5}$ A previous study including 1,218 students from the American state of New York has reported findings similar to ours, with a significant association between delinquency and substance use. ${ }^{4}$

The higher percentage of antisocial behaviors among adolescents who used crack and/or cocaine in the past year may be explained by the stronger and faster effect of these substances on the human body. Crack consumption has been associated with multiple drug use and with delinquent and violent behavior. Crack users commonly engage in illegal activities in exchange for the drug or for money. ${ }^{43,44}$ Finally, violent deaths (e.g. murders) are also common among crack consumers. ${ }^{45}$

From a different standpoint, the use of crack does not seem to be more strongly associated with violence when compared with cocaine. When controlled for sociodemographic data (sex, ethnicorigin, and educational level), the results obtained for the two substances were similar with regard to violent behaviors. ${ }^{46}$ These results suggest that, in addition to the pharmacological effects of the drugs, other aspects related with the context in which individuals are embedded may facilitate violent behaviors, e.g. easy access to guns. ${ }^{46}$

In spite of the higher percentage of antisocial behaviors among crack and cocaine users, the percentage of criminal offences committed by youth who used marijuana in the past year was also significantly higher when compared with results obtained for adolescents who did not use the drug. This finding may suggest that, although marijuana is not considered a "heavy" drug by society in general and by adolescents in particular, its use is also associated with juvenile delinquency, ${ }^{37}$ e.g. involvement in gang fights, ${ }^{18,20}$ carrying guns, ${ }^{20}$ or having problems with the police. ${ }^{18,20}$ In addition, marijuana may lead to other drug use. ${ }^{37,45}$

Usually, marijuana users are considered to be responsible for less severe crimes, e.g. property crimes. ${ }^{20}$ Notwithstanding, one study conducted with 312 male and female adolescents deprived of freedom revealed a significant association between marijuana use and criminal offences. ${ }^{47}$ Marijuana has been associated with juvenile delinquency in several studies, confirming the high risk associated with this substance, despite the fact that this perception is not shared by adolescents. ${ }^{1}$

Some limitations of the present study deserve to be mentioned. Although our sample was large, it included specifically adolescents in social vulnerability situation. As a result, our sample cannot be considered representative of Brazilian adolescents in general, although it may point 
to characteristics present in most of them. Moreover, limitations inherent to the questionnaire used for data collection should be taken into account. For example, the instrument included a high number of questions, making it difficult for adolescents to correctly answer all questions (several questions were left blank or only partially answered). Thus, future studies should try to limit the number of questions to be answered by participants, in an attempt to avoid loss of data. Another relevant aspect is the cross-sectional design of our study, which does not allow to imply cause and effect relationships. Longitudinal studies are warranted to better assess the development of the association between drug use and antisocial behaviors.

\section{Conclusions}

Our results revealed a high number of Brazilian adolescents using alcohol and cigarettes, which underscores the need to implement and continuously evaluate strategies directed at minors and aimed at preventing alcohol and cigarette use, especially in highrisk populations. ${ }^{15}$ Moreover, prevention and intervention strategies focusing on illicit substance use should be planned within the context of adolescence, and should include the investigation of risk and protective factors.

Finally, further studies designed to longitudinally assess drug use and involvement in antisocial behaviors are of paramount importance. Such studies would help find out whether the use of drugs takes place before or after criminal offences, allowing for the development of more effective prevention and intervention measures. Studying this association is relevant because it provides rationale on how to prevent or reduce substance use and antisocial behaviors. It has been suggested that prevention programs aimed at reducing the regular use of both licit and illicit substances, or at postponing drug use initiation, would cause a positive impact on delinquent behavior. ${ }^{37}$ Wainer $^{48}$ also supports this hypothesis, by mentioning that the prevention of any of these factors would positively affect other related factors.

The development of prevention and coping programs focusing on the consumption of alcohol and other drugs involve social, political educational, and cultural issues judicial measures alone have proved ineffective in reducing violence. ${ }^{49}$ In Chile, the understanding that multiple factors, including personality traits and cultural background, lead to antisocial behaviors has determined changes to prevention strategies in the sense of broadening the scope of interventions, covering different risk factors associated with antisocial behaviors, e.g. school attendance. ${ }^{50}$ In Brazil, in turn, prevention projects aimed at adolescents with antisocial behaviors are scarce. ${ }^{51}$ Programs focusing on primary prevention are indicated, so as to provide the necessary support for adolescents to develop their own opinions and not consume substances or use guns just to please their peers. Finally, offering treatment programs to drug users is important an important form of secondary and tertiary prevention. ${ }^{51}$

Problematic drug use among criminal offenders provides grounds for concern because of the higher probability that these adolescents will commit a new offence. ${ }^{42}$ Taking into consideration the association between drug consumption and criminal offences shown in our study, in addition to the inherent damaging effects of drug use, it is important that actions aimed at both the prevention and treatment of drug use and dependence be planned as part of public health policies directed to the adolescent population.

\section{References}

1. Anderson NLR. Perceptions about substance use among male adolescents in juvenile detention. West J Nurs Res. 1999;21:652-72.

2. Fergusson DM, Lynskey MT, Horwood LJ. Alcohol misuse and juvenile offending in adolescence. Addiction. 1996;91:483-94.

3. Macgarvey EL, Canterbury RJ, Waite D. Delinquency and family problems in incarcerated adolescents with and without a history of inhalant use. Addict Behav. 1996;21:537-42.

4. Mason WA, Windle M. Reciprocal relations between adolescent substance use and delinquency: a longitudinal latent variable analysis. J Abnorm Psychol. 2002;111:63-76.

5. Minayo MC, Deslandes SF. A complexidade das relações entre drogas, álcool e violência. Cad Saude Publica. 1998;14:35-42.

6. Pacheco JTB. A construção do comportamento anti-social em adolescentes autores de atos infracionais: uma análise a partir das práticas educativas e dos estilos parentais [tese]. Porto Alegre: Universidade Federal do Rio Grande do Sul; 2004.

7. Pereira SEFN, Sudbrack MFO. Drogadição e atos infracionais na voz do adolescente em conflito com a lei. Psicol Teor Pesq. 2008;24:151-9.

8. Shoemaker DJ. Theories of delinquency: an examination of explanations of delinquent behavior. 4th ed. New York: Oxford University Press; 2000.

9. Feijó MC, Assis SG. O contexto de exclusão social e de vulnerabilidade de jovens infratores e de suas famílias. Estud Psicol. 2004;9:157-66.

10. Silva DFM, Hutz CS. Abuso infantil e comportamento delinquente na adolescência: prevenção e intervenção. In: Hutz CS, editor. Situações de risco e vulnerabilidade na infância e na adolescência: aspectos teóricos e estratégias de intervenção. São Paulo: Casa do Psicólogo; 2002. p. 151-85.

11. Marques AC, Cruz M. O adolescente e o uso de drogas. Rev Bras Psiquiatr. 2000;22(Supl II):32-6.

12. Schenker M, Minayo MCS. Fatores de risco e de proteção para o uso de drogas na adolescência. Cienc Saude Coletiva. 2005; 10:707-17.

13. Carlini EA, Galduróz J, Silva A, Noto A, Fonseca A, Carlini $M$, et al. II Levantamento Domiciliar sobre o Uso de Drogas Psicotrópicas no Brasil: estudo envolvendo as 108 maiores cidades do país. São Paulo: Centro Brasileiro de Informações sobre Drogas Psicotrópicas, Universidade Federal de São Paulo; 2006. 
14. Laranjeira R, Pinsky I, Caetano R. I Levantamento Nacional sobre os Padrões de Consumo de Álcool na População Brasileira. Brasília: Secretaria Nacional Antidrogas; 2007.

15. Vieira D, Ribeiro M, Romano M, Laranjeira R. Álcool e adolescentes: um estudo para implementar políticas municipais. Rev Saude Publica. 2007;41:396-403.

16. United Nations Office on Drugs and Crime (UNODC). Relatório mundial sobre drogas WDR 2010. http://www.unodc.org/documents/southerncone//Topics_drugs/WDR/2010/WDR_2010_ Referencias_ao_Brasil_e_Cone_Sul.pdf. Accessed 2010 Jun.

17. McManus M, Alessi NE, Grapentine WL, Brickman A. Psychiatric disturbance in serious delinquents. J Am Acad Child Psychiatry. 1984;23:602-15.

18. White HR, Tice PC, Loeber R, Stouthamer-Loeber M. Illegal acts committed by adolescents under the influence of alcohol and drugs. J Res Crime Delinq. 2002;39:131-52.

19. Veirmeiren R. Psychopathology and delinquency in adolescents: a descriptive and developmental perspective. Clin Psychol Rev. 2003;23:277-318.

20. Dawkins MP. Drug use and violent crime among adolescents. Adolescence. 1997;32:395-405.

21. Taylor J, Malone S, Iacono WG, McGue M. Development of substance dependence in two delinquency subgroups and nondelinquents from a male twin sample. J Am Acad Child Adolesc Psychiatry. 2002;41:386-93.

22. Priuli RMA, Moraes MS. Adolescentes em conflito com a lei. Cienc Saude Coletiva. 2007;12:1185-92.

23. Fagan J. Set and setting revisited: influences of alcohol and illicit drugs on the social context of violent events. In: Martin SE, editor. Alcohol and interpersonal violence: fostering multidisciplinary perspectives. Rockville: National Institute of Health; 1993. p. 161-91. (NIAAA Research Monographs no. 24).

24. Forster LMK, Tannhauser SL, Barros HMT. Drug use among street children in southern Brazil. Drug Alcohol Depend. 1996;43:57-62.

25. Lang AR. Alcohol-related violence: psychological perspectives. In: Martin SE, editor. Alcohol and interpersonal violence: fostering multidisciplinary perspectives. Rockville: National Institute of Health; 1993. p. 121-47. (NIAAA Research Monographs no. 24).

27. Carvalho MCN, Gomide PIC. Práticas educativas parentais em famílias de adolescentes em conflito com a lei. Estud Psicol. 2005;22:263-75.

26. Loeber R, Hay D. Key issues in the development of aggression and violence from childhood to early adulthood. Annu Rev Psychol. 1997;48:371-410.

28. Nardi FL. Adolescentes em conflito com a lei: percepções sobre família, ato infracional e medida socioeducativa [dissertação]. Porto Alegre: Universidade Federal do Rio Grande do Sul; 2010.

29. Young SF, Miyake NA, Willcutt E, Corley R, Haberstick B, Hewitt J. Behavioral disinhibition: liability for externalizing spectrum disorders and its genetic and environmental relation to response inhibition across adolescence. J Abnorm Psychol. 2009;118:117-30.

30. Souza N, Grevet E, Salgado C, Silva K, Victor M, Karam R, et al. Smoking and ADHD: an evaluation of self medication and behavioral disinhibition models based on comorbidity and personality patterns. J Psychiatr Res. 2011;45:829-34.

31. Dinn W, Aycicegi A, Harris C. Cigarette smoking in a student sample: neurocognitive and clinical correlates. Addict Behav. 2004;29:107-26.

32. Libório RMC, Koller SH. Adolescência e juventude: risco e proteção na realidade brasileira. São Paulo: Casa do Psicólogo; 2009.

33. World Health Organization. Participant manual: IMAI oneday orientation on adolescents living with HIV. http://whqlibdoc.who.int/publications/2010/9789241598972_eng.pdf. Accessed 2010 Sep.
34. Koller SH, Morais NA, Cerqueira-Santos E. Adolescentes e jovens brasileiros: levantando fatores de risco e proteção. In: Libório RM, Koller SH, editores. Adolescência e juventude: risco e proteção na realidade brasileira. São Paulo: Casa do Psicólogo; 2009. p. 17-56.

35. Galduróz J, Noto A, Fonseca A, Carlini EA. V Levantamento sobre o Consumo de Drogas Psicotrópicas entre Estudantes de Ensino Fundamental e Médio da Rede Pública de Ensino nas 27 Capitais Brasileiras. São Paulo: Centro Brasileiro de Informações sobre Drogas Psicotrópicas; 2004.

36. Brasil. Estatuto da criança e do adolescente. Lei no. 8069/1990. http://www.planalto.gov.br/ccivil_03/leis//8069.htm. Accessed 2010 Sep.

37. Hays RD, Ellickson PL. Associations between drug use and deviant behavior in teenagers. Addict Behav. 1996;21:291-302.

38. Instituto Latino-Americano das Nações Unidas para Prevenção do Delito e Tratamento do Delinquente. http://portal. mj.gov.br/sedh/spdca/ppcaam/pub_ppcaam2008.pdf. Accessed 2010 Sep 09.

39. Assis SG, Souza ER. Criando Caim e Abel: pensando a prevenção da infração juvenil. Cienc Saude Coletiva. 1999;4:131-44.

40. Frias-Armenta M, Lopez-Escobar AE, Diaz-Mendez SG. Predictores de la conducta antisocial juvenil: un modelo ecológico. Estud Psicol. 2003;8:15-24.

41. Gallo A, Williams LCA. A escola como fator de proteção à conduta infracional de adolescentes. Cad Pesq. 2008;38:41-59.

42. Simone MR. O uso de drogas pelos adolescentes autores de ato infracional na cidade de Porto Alegre: uma questão só de polícia? [monografia]. Porto Alegre: Escola Superior do Ministério Público do Rio Grande do Sul; 2001.

43. Guimarães C, Santos D, Freitas R, Araújo R. Perfil do usuário de crack e fatores relacionados à criminalidade em unidade de internação para desintoxicação no Hospital Psiquiátrico São Pedro de Porto Alegre (RS). Rev Psiquiatr Rio Gd Sul. 2008;30:101-8.

44. Oliveira L, Nappo S. Caracterização da cultura de crack na cidade de São Paulo: padrão de uso controlado. Rev Saude Publica. 2008;42:664-71.

45. Cartwright WS, Kitsantas P, Rose SR. A demographic-economic model for adolescent substance abuse and crime prevention. J Comp Soc Welfare. 2009;25:157-72.

46. Vaughn MG, Fu Q, Perron BE, Bohnert AS, Howard MO. Is crack cocaine use associated with greater violence than powdered cocaine use? Results from a national sample. Am J Drug Alcohol Abuse. 2010;36:181-6.

47. Martins MC, Pillon SC. A relação entre a iniciação do uso de drogas e o primeiro ato infracional entre os adolescentes em conflito com a lei. Cad Saude Publica. 2008;24:1112-20.

48. Wainer FW. Infractores de ley, consumo problemático de drogas y posibilidades de intervención. Rev El Observador. 2008;2:9-26.

49. Gallo AE. Atuação do psicólogo com adolescentes em conflito com a lei: a experiência do Canadá. Psicol Estud. 2008; 13:327-34.

50. Wainer FW. Prevención social del delito: pautas para una intervención temprana en niños y jóvenes. München/Santiago: Fundación Hanns Seidel Stiftung/Fundación Paz e Ciudadana; 2006. http://www.pazciudadana.cl/docs/ pub_20090618132605.pdf. Accessed 2010 Aug 28.

51. Assis SG, Constantino P. Perspectivas de prevenção da infração juvenil masculina. Cienc Saude Coletiva. 2005;10:81-90.

\section{Correspondence}

Fernanda Nardi

Núcleo de Estudos e Pesquisas em Adolescência (NEPA)

Rua Ramiro Barcelos, 2600/115

90035-003 - Porto Alegre, RS - Brazil

E-mail: fernanda.nardi@yahoo.com.br 